\title{
Pengembangan Kuliner Berbahan Baku Salak Di Desa Wisata Mranggen
}

\author{
Triwara Buddhi Satyarini*1 \\ Program Studi Agribisnis, Universitas Muhammadiyah Yogyakarta, J. Brawijaya, Tamantirto, Kasihan, Bantul, D.I. Yogyakarta \\ ${ }^{*}$ Email: triwara@umy.ac.id
}

DOI: $10.18196 / p p m \cdot 32.220$

\begin{abstract}
Abstrak
Desa Mranggen telah mendapatkan mandat sebagai Desa Wisata \& Budaya dari Dinas Pariwisata Kabupaten Magelang sejak tahun 2017 mengingat beberapa potensi yang dimiliki, baik potensi alam maupun potensi sosial budaya yang lain. Potensi yang memerlukan perhatian dan pengembangan lebih lanjut dalam rangka inisiasi desa wisata antara lain kuliner berbahan baku salak yang merupakan hasil pertanian lokal. Untuk meningkatkan potensi tersebut agar bisa menunjang realisasi Desa Wisata, dilakukan pelatihan pembuatan aneka olahan berbahan baku salak yang diharapkan bisa menjadi oleh-oleh khas dari Desa Wisata Mranggen. Macam olahan yang sudah dilakukan pelatihan antara lain dodol salak, cookies salak, brownies salak dan donat salak, Selain pelatihan diversifikasi olahan berbahan baku buah salak tersebut, juga diberikan pelatihan dan pengembangan pemasarannya, termasuk dibentuknya outlet-outlet penjualan produknya.
\end{abstract}

Kata kunci : kuliner, desa wisata, pengembangan, pemasaran

\section{Pendahuluan}

Desa Mranggen, terletak di sisi barat Gunung Merapi berjarak $11 \mathrm{~km}$ dari Puncak Merapi. Desa Mranggen merupakan salah satu desa yang berbatasan langsung dengan area Taman Nasional Gunung Merapi yang berjarak 6 km dari Desa Mranggen. Desa Mranggen memliki empat belas pedukuhan (dusun). Dua dusun yang dijadikan mitra dalam PKM ini adalah Dusun Sunggingsari dan Mranggensari. Dua dusun ini merupakan dusun penyangga dalam rangka rintisan Desa Mranggen menjadi desa wisata untuk pengembangan kulinernya. Pada dasarnya, hampir semua dusun di Mranggen menghasilkan bahan baku yang bisa dikembangkan untuk diversifikasi kuliner.

Desa Mranggen berjarak 1,5 km dari pusat Kecamatan Srumbung berjarak $18.5 \mathrm{~km}$ dari pusat Kota Kabupaten Magelang dan berjarak $60 \mathrm{~km}$ dari Ibukota Provinsi Jateng di Semarang. Luas wilayah Desa Mranggen 416,8 hektare yang terdiri atas lahan pemukiman 61,75 ha, persawahan 286,69 ha, perkebunan 55,71 ha, tanah kering 117,46 ha (tegal, pekarangan), dan sisanya untuk sarana umum. Memiliki aset tanah kas desa seluas 123,95 ha berupa lahan kering dan sawah. Sebagian besar sawah ditanami padi, palawija, serta sayuran. Sementara lahan tegal dan pekarangan didominasi oleh tanaman salak pondoh. Jumlah penduduk laki-laki sebanyak 2.224 jiwa dan wanita 2.238 jiwa. Terdapat $1.382 \mathrm{KK}$ dengan pekerjaan dominan sebagai petani, yakni $1.132 \mathrm{KK}, 89$ pengrajin industri rumah tangga, sisanya ada pegawai, peternak, pedagang, buruh, dan lain sebagainya.

\section{a. Perintisan Desa Wisata \& Budaya}

Desa Mranggen telah mendapatkan mandat sebagai Desa Wisata \& Budaya dari Dinas Pariwisata Kabupaten Magelang sejak tahun 2017 mengingat beberapa potensi, baik potensi alam maupun potensi sosial budaya. Beberapa potensi alam layak yang dikembangkan menjadi wisata di Desa Mranggen sebagai berikut.

Desa Mranggen dilewati jalur utama dari Magelang ke Taman Nasional Gunung Merapi (TNGM), tetapi jalur ini tidak sepopuler jalur lain, seperti jalur ke Gardu Pandang Ketep atau jalur ke arah Wisata Kopeng. Jalur ini, tiga tahun terakhir mulai ramai semenjak TNGM 
dimanfaatkan sebagai wahana wisata. Merespons perkembangan ramainya lalu lintas Jalan Magelang ke TNGM ini, pemerintah Desa Mranggren bermaksud membangun kawasan pusat pemerintahan terpadu di pinggir jalur Mranggen-TNGM-Merapi. Pemerintah mengalihfungsikan lahan seluas 2 ha. Sekarang sudah dimulai pembangunan Kantor Desa Mranggen yang baru yang terintegrasi dengan fasilititas rest area.

Telah muncul gagasan bahwa Desa Mranggen akan dikembangkan menjadi Desa Wisata Surya Buana. Pengembangan desa wisata dapat mengikuti konsep empat A yang dikembangkan oleh Echtner (2002), yaitu : sajian wisata (attractions), pelaku atau pengelola wisata (actors), pelaksanaan (actions) dan daya dukung masyarakat (atmospheres). Sementara Desa Wisata Surya Buana adalah brand atau ciri khas yang akan dibangun dan melekat pada wisata di Desa Mranggen. Konsep branding dalam wisata juga dikenalkan oleh Pike (2005). Konsep ini bertujuan menjadi daya tarik yang tidak mudah tergantikan oleh yang lain.

Salah satu dari konsep empat A yang perlu segera diaktifkan dan ditambah wawasannya adalah daya dukung masyarakat(atmosphere) dengan memanfaatkan potensi desa sebagai penghasil buah salak untuk dibuat diversifikasi olahannya untuk dijadikan produk unggulan oleh-oleh dari daerah wisata setempat.

\section{b. Permasalahan Mitra dalam Pengembangan Desa Wisata}

Mitra dalam program pengabdian ini adalah masyarakat dan pemerintah Desa Mranggen dengan sasaran strategisnya yakni Pengelola Desa Wisata (Pokdarwis) dan kelompok pengembang kuliner berbahan baku hasil pertanian setempat di Desa Mranggen, Kecamatan Srumbung, Kabupaten Magelang. Desa Mranggen telah mendapat mandat sebagai Desa Wisata \& Budaya dari Dinas Pariwisata Kabupaten Magelang sejak tahun 2017 mengingat memiliki beberapa potensi, baik potensi alam maupun potensi sosial budaya yang lain.

Dibalik potensi pengembangan Desa Mranggen menjadi Desa Wisata dan Budaya, terdapat beberapa permasalahan dalam A ke empat, yaitu peningkatan daya dukung masyarakat (atmospher). Dari survei awal diketahui bahwa belum banyak warga yang tahu secara pasti bahwa Desa Mranggen akan dijadikan desa wisata karena belum ada sosialisasi secara pasti tentang desa wisata, khususnya kuliner yang akan dijadikan produk oleh-oleh pendukung desa wisata.

Tabel 1. Prioritas Masalah Pengembangan Desa Wisata Mranggen

\begin{tabular}{|c|c|c|}
\hline Kelompok Masalah & No & Rincian Masalah \\
\hline $\begin{array}{l}\text { Pengorganisasian Pelaku Desa Wisata } \\
\text { (Actor) }\end{array}$ & 1. & $\begin{array}{l}\text { Belum ada tim pengelola inti yang bertanggung jawab terhadap pengelolaan aktivitas desa } \\
\text { wisata secara bisnis atau komersil. Selama ini, tugas terkait dengan desa wisata masih } \\
\text { menjadi beban Pokdarwis dan pengelolaannya masih bersifat social. }\end{array}$ \\
\hline \multirow[t]{2}{*}{$\begin{array}{l}\text { Pengemasan } \\
\text { (Attraction) }\end{array}$} & 2. & $\begin{array}{l}\text { Belum adanya paket-paket sajian wisata yang akan ditawarkan kepada wisatawan, } \\
\text { khusunya sajian kuliner khas Mranggen yang menarik bagi wisatawan. }\end{array}$ \\
\hline & 3. & $\begin{array}{l}\text { Belum memiliki kelompok-kelompok khusus yang bertanggungjawab terhadap sajian } \\
\text { wisata yang berpeluang menjadi paket wisata, kelompok kesenian dan budaya, kelompok } \\
\text { kerajinan dan lain sebagainya khususnya kelompok kuliner. }\end{array}$ \\
\hline $\begin{array}{l}\text { Perencanaan Sarana- Prasarana } \\
\text { (Accomodation) }\end{array}$ & 4. & $\begin{array}{l}\text { Belum ada kajian dan perencanaan untuk menyiapkan sarana dan prasarana desa wisata, } \\
\text { khusunya tempat kuliner. }\end{array}$ \\
\hline $\begin{array}{l}\text { Peningkatan daya dukung Masyarakat } \\
\text { (Atmosfeer) }\end{array}$ & 5. & $\begin{array}{l}\text { Dari survei awal diketahui bahwa hanya sekitar } 30 \% \text { warga yang tahu secara pasti bahwa } \\
\text { Desa Mranggen akan dijadikan desa wisata karena belum ada sosialisasi secara pasti } \\
\text { tentang desa wisata, khususnya kulinernya yang khas. }\end{array}$ \\
\hline
\end{tabular}




\section{c. Solusi (Pemeeahan Masalah) yang Ditawarkan}

Tabel 2. Solusi yang ditawarkan berdasarkan rincian masalah

\begin{tabular}{|c|c|c|}
\hline No & Rincian Masalah & Solusi yang ditawarkan \\
\hline 1. & $\begin{array}{l}\text { Belum ada tim pengelola inti yang bertanggung jawab terhadap } \\
\text { pengelolaan aktivitas desa wisata secara bisnis atau komersil. } \\
\text { Selama ini, tugas terkait dengan desa wisata masih menjadi } \\
\text { beban Pokdarwis dan pengelolaannya masih bersifat social. }\end{array}$ & $\begin{array}{l}\text { Dari Pokdarwis yang sudah terbentuk, akan segera ditetapkan } \\
\text { kelompok kuliner dan model partisipasinya dalam } \\
\text { pengembangan kuliner khas, baik makanan, minuman, dan } \\
\text { oleh-oleh khas }\end{array}$ \\
\hline 2. & $\begin{array}{l}\text { Belum adanya paket-paket sajian wisata yang akan ditawarkan } \\
\text { kepada wisatawan, khusunya sajian kuliner khas Mranggen } \\
\text { yang menarik bagi wisatawan }\end{array}$ & $\begin{array}{l}\text { Akan dibentuk branding kuliner khas Mranggen. Hal ini } \\
\text { sesuai dengan ciri khas jalur wisata dan tipologi alamnya yang } \\
\text { menghasilkan buah salak. }\end{array}$ \\
\hline 3. & $\begin{array}{l}\text { Belum memiliki kelompok-kelompok khusus yang } \\
\text { bertanggung jawab terhadap sajian wisata yang berpeluang } \\
\text { menjadi paket wisata, kelompok kesenian dan budaya, } \\
\text { kelompok kerajinan dan lain sebagainya, khususnya kelompok } \\
\text { kuliner. }\end{array}$ & $\begin{array}{l}\text { Akan dibentuk penanggung jawab dan pengembang kuliner } \\
\text { khas Mranggen, baik makanan maupun minumannya. }\end{array}$ \\
\hline 4. & $\begin{array}{l}\text { Belum ada kajian dan perencanaan untuk menyiapkan sarana } \\
\text { dan prasarana desa wisata, khusunya tempat kuliner }\end{array}$ & $\begin{array}{l}\text { Akan dikaji dan diusulkan minimal satu tempat sebagai } \\
\text { warung yang menjajakan olahan salak. }\end{array}$ \\
\hline 5. & $\begin{array}{l}\text { Dari survei awal, diketahui bahwa hanya sekitar } 30 \% \text { warga } \\
\text { yang tahu secara pasti bahwa Desa Mranggen akan dijadikan } \\
\text { desa wisata karena belum ada sosialisasi secara pasti tentang } \\
\text { desa wisata, khususnya kuliner khas }\end{array}$ & $\begin{array}{l}\text { Akan diadakan sosialisasi dan lomba sajian kuliner khas } \\
\text { Mranggen se-Desa Mranggen sebagai upaya pengodisian dan } \\
\text { sarana awarreness bagi masyarakat setempat }\end{array}$ \\
\hline
\end{tabular}

\section{d. Metode Pemecahan Masalah dan Target Luaran}

Metode pemecahan masalah serta target pertama dan luaran dari kegiatan yang dilakukan dalam rangka pemecahan masalah adalah sebagai berikut.

Tabel 3. Target Luaran Berdasarkan Solusi Masalah

\begin{tabular}{ccc}
\hline No & \multicolumn{1}{c}{ Metode Pemecahan Masalah } & \multicolumn{1}{c}{ Target dan Luaran } \\
\hline $1 . \quad \begin{array}{l}\text { Akan dilakukan FGD dengan Pokdarwis sehingga ditetapkan } \\
\text { pengurus yang bertanggung jawab pada sajian kuliner khas } \\
\text { wisata Mranggen. Dari pengurus yang ditetapkan akan } \\
\text { dijadikan Team Work yang akan bekerja sebagai penangggung } \\
\text { jawab Festival Kuliner dan Wedang Ereng-ereng }\end{array}$ & $\begin{array}{l}\text { Terbentuk 1 Team Work yang terdiri atas elemen pengurus } \\
\text { Pokdarwis, tokoh Ibu2 PKK Dusun Gondangsari, Rejosari, } \\
\text { Pringsari, serta tim pengusul dari pihak UMY }\end{array}$ \\
\hline 2. & $\begin{array}{l}\text { Akan dilakukan sosialisasi kegiatan diversifikasi olahan salak } \\
\text { ke seluruh wilayah Desa Mranggen yang berisi informasi dan } \\
\text { penyadaran pentingnya membuat kuliner khas Mranggen } \\
\text { sebagai penghasil buah salak untuk mendukung Mranggen } \\
\text { sebagai desa wisata }\end{array}$ & $\begin{array}{l}\text { Dilaksanakan sosialisasi lewat peretemuan PKK Desa/Dusun } \\
\text { serta publikasi lewat selebaran dan surat resmi dari desa }\end{array}$ \\
\hline 3. & $\begin{array}{l}\text { Pelaksanaan pelatihan olahan yang diikuti oleh } \\
\text { seluruh/perwakilan tiap dusun dan komponen masyarakat Desa } \\
\text { Mranggen, serta diakhiri dengan lomba hasil praktik mandiri } \\
\text { setelah pelatihan }\end{array}$ & $\begin{array}{l}\text { Terlaksananya 1-3 kali kegiatan pelatihan olahan berbahan } \\
\text { baku salak dan hasil pertanian setempat yang diikuti oleh } \\
\text { perwakilan 2-3 tim/dusun }\end{array}$ \\
\hline
\end{tabular}

Dari target yang ditetapkan, telah dilaksanakan tiga kali pelatihan olahan berbahan baku salak dan cara pemasarannya. Seharusnya, masih diperlukan beberapa kali pelatihan agar masyarakat setempat betul-betul termotivasi untuk berinovasi dalam bidang kuliner berbahan baku hasil pertanian setempat. Namun, dengan adanya pandemi Covid-19 terpaksa pelatihan belum bisa dilanjutkan. 


\section{Metode Pelaksanaan}

Metode dasar dalam kegiatan ini adalah dengan peningkatan pengetahuan dan keetrampilan serta fasilitasi dalam pengembangan pemasaran. Sementara upaya promosi, rencana awalnya, akan dilakukan dengan mengundang masyarakat Desa Mranggen dan wisatawan dalam kegiatan festival kuliner berbahan baku salak. Metode FGD banyak dilakukan untuk merembuk perencanaan kegiatan dengan melibatkan seluruh stakeholder, yakni panitia festival, pengurus Pokdarwis, pengelola desa wisata, perwakilan pemerintah Desa Mranggen dan seluruh pedukuhan, serta kelompok pengembang yang akan dilatih dan difasilitasi dalam rangka pemasaran olahan salak. Fasilitasi outlet penjualan dilakukan terhadap lima orang yang diyakini siap secara teknis dan memiliki motivasi kuat untuk mengembangkan kuliner olahan salak.

\section{Hasil dan Pembahasan}

Program pengabdian masyarakat yang telah terlaksana adalah pelatihan olahan makanan berbahan baku salak dan pengembangan pemasaran di Desa Mranggen bersamaan dengan dilaksanakannya KKN mahasiswa UMY sehingga pelaksanaan pelatihan bisa mendapatkan bantuan/melibatkan mahasiswa KKN.

Pelatihan baru terlaksana tiga kali, yaitu pelatihan pembuatan cookies salak dan dodol salak, pelatihan pembuatan brownies salak dan donat salak,

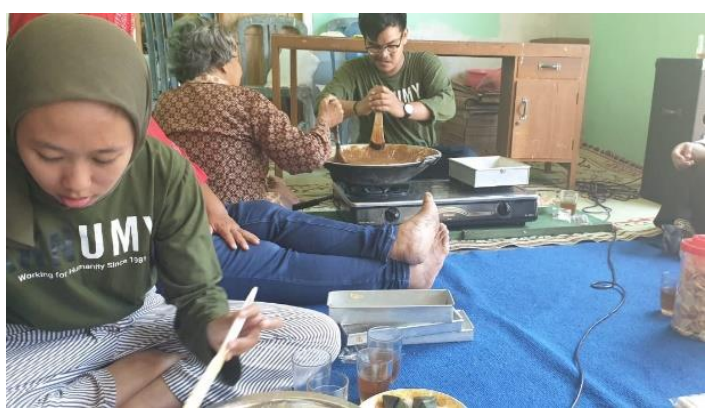

Gambar 1. Proses Pengolahan Dodol Salak serta pelatihan/penyuluhan tentang pengembangan pemasaran produk lokal setempat. Inovasi tentang olahan berbahan baku buah salak untuk mengantisipasi fluktuasi hasil dan harga buah salak juga untuk mendukung keberadaan Desa Mranggen sebagai desa wisata mengingat lokasi wisata tidak bisa dipisahkan dengan buah tangan.

Seperti diketahui bahwa buah salak bersifat musiman. Artinya, pada saat sedang musim, ketersediaannya sangat banyak, tetapi harga menjadi murah. Kondisi ini mengakibatkan pendapatan petani turun pendapatannya. Agar harga bisa bertahan tidak terlalu jatuh, dibuat olahan berbahan baku salak. Hal ini bertujuan agar buah salak bisa dimanfaatkan secara optimal, terutama saat sedang musim. Dengan demikian, bisa menurunkan ketersediaannya sebagai buah segar yang diharapkan harganya menjadi lebih baik, tidak terlalu rendah.

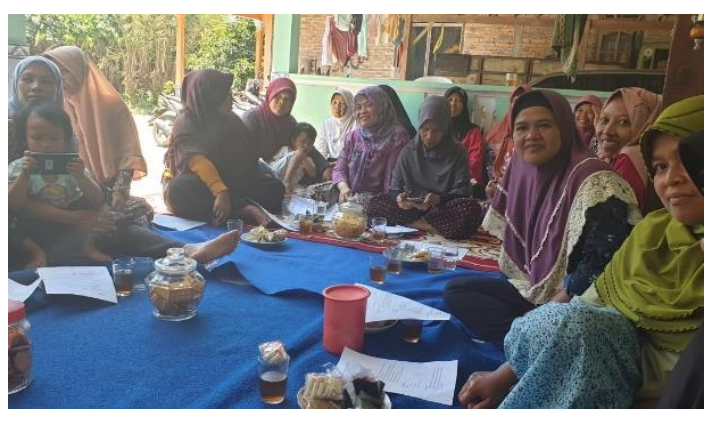

Gambar 2. Sosialisasi tentang Pemasaran Produk Olahan Salak

Banyak macam pangan olahan yang bisa dibuat dari buah salak. Namun, pada pelaksanaan pelatihan olahan, baru empat macam yang bisa diberi pelatihan karena terhalang pandemi Covid-19 yang sampai sekarang belum berakhir. Rencananya, setelah lebih banyak macam pelatihan olahan, akan diakhiri dengan semacam lomba atau festival kuliner berbahan baku salak untuk memotivasi warga setempat supaya banyak menghasilkan ide pembuatan kuliner berbahan baku salak. Dengan adanya wabah Covid-19, lomba/ festival tersebut belum terlaksana. Semoga di waktu yang akan datang, lomba/ festival tersebut bisa terselenggara setelah kondisi aman.

Selain diberikan pelatihan tentang variasi pangan olahan, juga diberikan pelatihan 
tentang pemasarannya yang meliputi strategi pemasaran, termasuk cara dan bentuk kemasan, jaringan pemasaran sampai dengan desain pesan pemasaran yang bisa diaplikasikan. Hal ini bertujuan agar produk-produk pangan olahan/oleh-oleh bisa banyak dikenal calon pengunjung dan menarik sehingga bisa menjadi ikon kuliner Desa Wisata Mranggen. Selain pelatihan, juga diberikan sarana untuk memajang produk yang dihasilkan untuk kepentingan pemasaran.

Secara umum pengembangan kuliner khas di Desa Wisata sejalan dengan konsep empat A yang dikembangkan oleh Echtner (2002), yaitu : sajian wisata (attractions), pelaku atau pengelola wisata (actors), pelaksanaan (actions) dan daya dukung masyarakat (atmospheres). Pengembangan Wedang Ereng-ereng diharapkan bisa meciptakan brand dan menjadi salah satu daya tarik serta penciri wisata sebagaimana yang dilakukan oleh Pike (2005). Korelasi pemasaran, daya tarik wisata, dan kunjungan wisata telah diteliti oleh Widagdyo (2017). Hasilnya menyebutkan bahwa kuliner merupakan salah satu bagian dari faktor daya tarik petualangan dan budaya.

Pengembangan pemasaran kuliner berbahan baku salak dalam kegiatan ini sesungguhnya mengikuti konsep bauran pemasaran wisata yang pernah diteliti oleh Yulita (2016) karena diyakini akan meningkatkan keputusan wisatawan untuk berkunjung ke Desa Wisata. Kegiatan ini masih memerlukan tindak lanjut, yaitu

1. Pelatihan lanjutan untuk lebih banyak memberikan variasi produk dan kalau memungkinkan sampai ke pendaftaran merek dagangnya. Hal ini

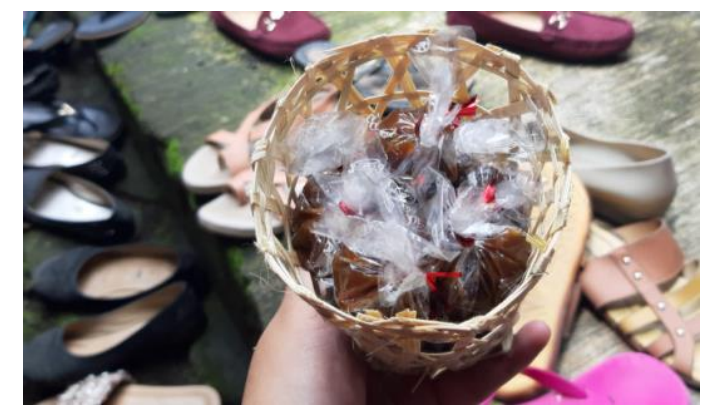

Gambar 3. Produk Dodol Salak bertujuan untuk menjaga agar tidak terjadi konflik kepentingan bisnis dan menjaga agar masyarakat yang menjadi pelaku utama akan memperoleh manfaat yang sebesar-besarnya

2. Diperlukan upaya promosi yang lebih masif yang bertumpu pada kepentingan masyarakat atau kelompok pengembang sehingga kuliner berbahan baku buah salak makin banyak macamnya, makin diminati, dan disukai oleh pengunjung desa wisata.

3. Diperlukan tindak lanjut pengembangan variasi olahan berbahan baku salak agar bisa menjadi buah tangan atau oleh-oleh yang praktis dan lebih marketable sehingga bisa dibawa pulang oleh para wisatawan yang datang ke Desa Wisata Mranggen.

\section{Kesimpulan}

1. Pelaksanaan pelatihan olahan berbahan baku buah salak dengan lebih banyak variasinya diharapkan bisa menjadi sarana sosialisasi dan promosi, baik ke dalam masyarakat sebagai upaya menggugah kesadaran dukungan terhadap desa wisata maupun promosi ke luar sebagai upaya meningkatkan daya tarik untuk berkunjung ke Desa Wisata Mranggen.

2. Standardisasi formula dan penjualan dilakukan agar produk memiliki standar kualitas dan standar harga yang ideal dan seragam untuk para pengembang. Hal ini bertujuan agar harga tetap terjangkau oleh konsumen dan tidak menyebabkan variasi harga yang berlebihan bagi produk yang sama.

3. Pihak desa sudah mengoordinasikan tempat-tempat penjualan, yakni beberapa konter yang dianggap strategis pada tahap awal pengembangan desa wisata. Di masa yang akan datang, masyarakat diharapkan bisa menyediakan juga konter penjualan secara mandiri, terutama di jalur-jalur utama yang akan dilewati wisatawan. 


\section{Ucapan Terima Kasih}

Kami mengucapkan terima kasih kepada Kepala LP3M UMY atas dukungan dana kegiatan abdimas ini. Selain itu, kami juga mengucapkan terima kasih kepada Kepala Desa Mranggen, seluruh kepala pedukuhan di Desa Mranggen, dan pengurus Desa Wisata Mranggen.

\section{Daftar Pustaka}

Echtner, C. M. (2002). The content of the third world tourism marketing: a 4A Approach. International Journal of Tourism Research, 4, 413-434.

Pike, S. (2005). Tourism destination branding complexity. The Journal of Product and Brand Management, 14/4, 258-259.

Widagdyo, K. G. (2017). Pemasaran, Daya Tarik Ekowisata dan Minat Berkunjung Wisatawan. Esensi : Jurnal Bisnis Dan Manajemen, 7(2), 261-276.

Yulita, H. (2016). Pengaruh Bauran Pemasaran Pariwisata Terhadap Keputusan Berkunjung. Jurnal Hospitality Dan Pariwisata, Volume 2 No 2. 